This item was submitted to Loughborough's Research Repository by the author.

Items in Figshare are protected by copyright, with all rights reserved, unless otherwise indicated.

\title{
Women responding to the anti-Islam film Fitna: voices and acts of citizenship on YouTube
}

PLEASE CITE THE PUBLISHED VERSION

http://dx.doi.org/10.1057/fr.2010.29

PUBLISHER

(C) Palgrave Macmillan

VERSION

AM (Accepted Manuscript)

LICENCE

CC BY-NC-ND 4.0

\section{REPOSITORY RECORD}

Vis, Farida, Liesbet van Zoonen, and Sabina Mihelj. 2019. "Women Responding to the Anti-islam Film Fitna: Voices and Acts of Citizenship on Youtube". figshare. https://hdl.handle.net/2134/13279. 
This item was submitted to Loughborough's Institutional Repository (https://dspace.lboro.ac.uk/) by the author and is made available under the following Creative Commons Licence conditions.

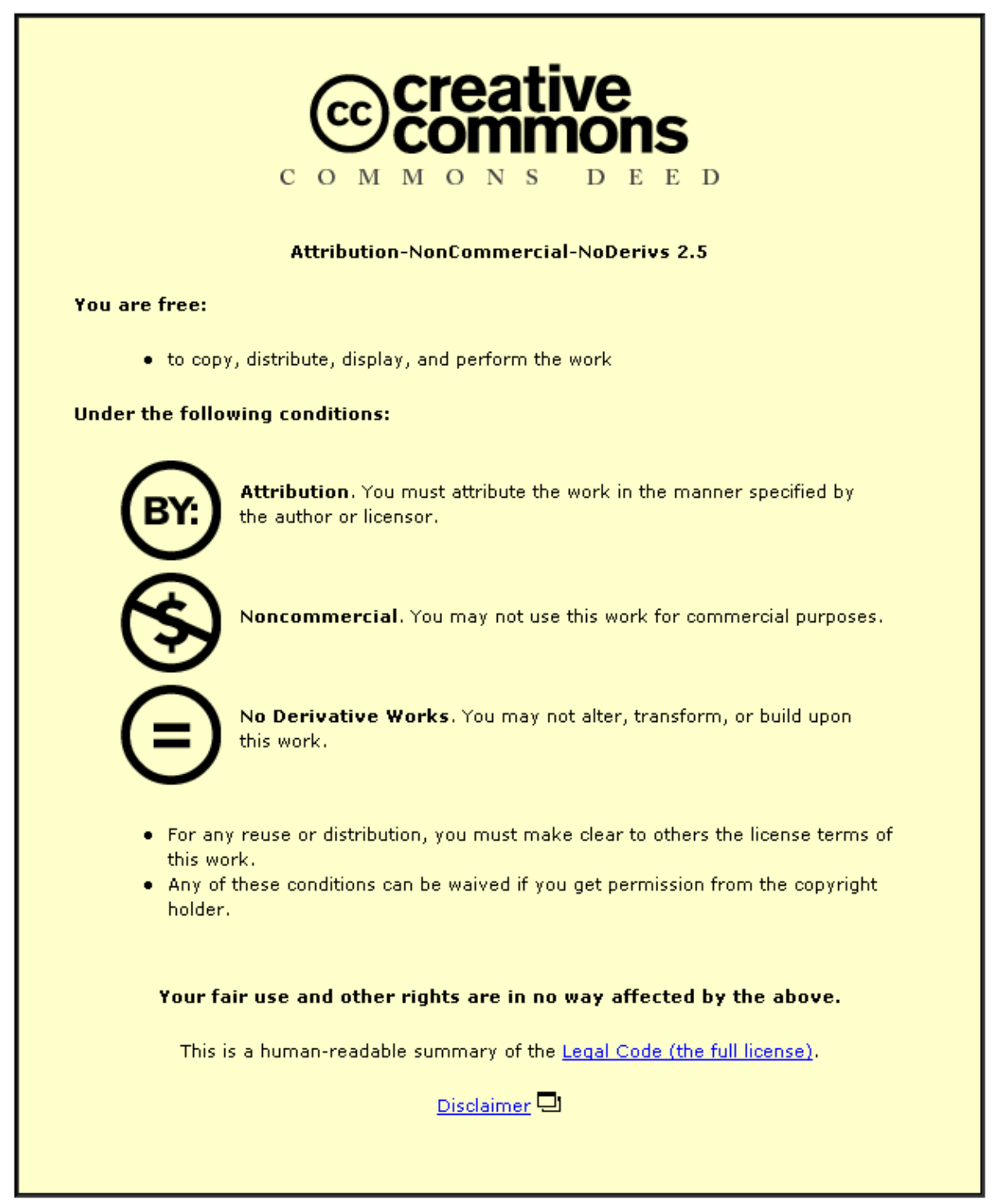

For the full text of this licence, please go to: http://creativecommons.org/licenses/by-nc-nd/2.5/ 


\section{Women responding to the anti-Islam film Fitna: voices and acts of citizenship on YouTube}

\section{Introduction}

In early March 2008, Dutch anti-Islam Member of Parliament Geert Wilders produced a 16-minute short video called Fitna to express in visual form his argument that Islam is a dangerous religion, and that the Netherlands is under the threat of a 'tsunami of Muslims ${ }^{\mathrm{i}}$. As no Dutch broadcaster wished to show it, the film, a compilation of existing audio-visual material was released on the internet (on Live Leak) and caused an immense debate in the Netherlands and abroad, comparable to the fall-out from the Danish cartoon crisis. Wilders' opponents accused him of visual demagogy, while his supporters praised him for having the courage to speak his mind. The debate was intense and focused primarily on the film itself, Wilders' motives and the question of whether Fitna should be banned or not (Ruigrok et al., 2008). Dutch journalists analysed the source material Wilders used in the film and found no original footage, but rather a compilation of re-mediated visual, statistical and written information: shocking fragments from existing Islamaphobic films, such as Obsession: Radical Islam's War against The West, and The Violent Oppression of Women in Islam; distorted statistics from Dutch and European government agencies that had already been recalled by these same agencies; and many newspaper headlines about Muslim fundamentalism, terrorist actions, threats to Wilders and other advocates of 'freedom of speech'; all interspersed with fragments of Quranic verses that allude to violence against non-Muslims (Choua and Kranenberg, 2008). 
Missing from these debates was and is a discussion of the way in which Wilders exploits images of gender and female bodies in particular to make his point against Islam. In this article we will first examine how Wilders' stereotypes of women and men come directly from traditional Orientalist discourse. The more important point of the article, however, is our analysis of the response videos that were produced and uploaded to YouTube by women from around the globe: in some cases to express their annoyance with Wilders, in other cases to show their own understanding of Islam. These videos are part of a larger number of protest and support videos that were uploaded to YouTube immediately after the film's release and in the following months. ${ }^{\text {ii }}$ Using quantitative and qualitative methods of analysis, we ask whether and how the representations of gender and Islam in Fitna differ from the videos made by female YouTube posters, and whether the latter articulate alternative narratives that depart from traditional Orientalist discourse. We examine, in addition, whether YouTube functioned as an online space that offered a voice to those who were not part of the Fitna debate in the mainstream media and what kind of voice this was.

In the final part of the paper we reflect on the wider implications of our findings, in particular from the point of view of the democratic potential of the internet and YouTube. To what extent did YouTube provide an alternative space for public debate about Islam and politics, and offer a space for the enactment of citizenship to those excluded from or marginalised in mainstream deliberations about Islam in the Western media - namely women, young people, and Muslims (Poole and Richardson, 2006; Richardson, 2006; Aly, 2009)? To address these issues, we draw on a theoretical 
framework that is built on the concepts 'acts of citizenship', 'multicultural democracy', 'voice' and 'listening'.

\section{Fitna and Orientalist discourse}

To understand how gender is exploited in Fitna, we first need to examine how women and men from Muslim and non-Muslim backgrounds are cast in the different roles of victim, perpetrator and hero.

Muslim women are shown in three ways in Fitna:

- as victims of extreme violence (there are short sequences on genital mutilation, showing a screaming woman and pool of blood at her feet, we see the still veiled head of a beheaded woman, a woman kneeling in front of group of men, one of whom points a machine gun at her head);

- as complicit in the encouragement of anti-Semitism and anti-Western feelings; for example three and half year old Basmallah, a little Palestinian girl wearing hijab, who proudly declares, encouraged by a woman out of view, that the Quran says that Jews are pigs and apes. We are shown a still of a smiling woman, also in hijab, holding up her blood soaked toddler following a religious ceremony. Finally, there are shots of women at demonstrations in full black niqab holding up radical slogans in praise of Hitler;

- as part of the allegedly changing Dutch landscape, the film includes shots of Muslim women wearing different kinds of headscarves, most notably black niqab, in everyday settings: with toddlers in pushchairs around town, in the park, at the market and so on. 
In stark contrast, non-Muslim women are shown exclusively as victims or as aid workers, and the film contains an especially harrowing sequence of a phone conversation between a woman stuck in one of the Twin Towers describing to the 911 operator that she is burning up and the emergency woman comforting her calmly and telling her to say her prayers.

Muslim men are either shown as radical preachers - such as the London based Imam Abu Hamza al Masri or Iraqi Sheik Bakr Al Samarai ${ }^{\text {iii }}$ - or as part of large groups, making it difficult to identify individuals (see Moore et al., 2008 for similar findings in recent coverage in the British national print media). These large groups of Muslim men include Hizbollah supporters, who collectively make what looks like the Nazi salute, shout at demonstrations with kaffiyehs covering their faces, hold up placards with slogans such as 'You will pay with your blood' and 'Freedom go to Hell!'. In a short sequence men wave bloody daggers in the air, images of hands, blood and daggers. A group of Muslim men talk about Islam being the best religion, saying that anyone who converts to Christianity deserves to die. The most excessive example of the portrayal of Muslim men as violent aggressors concerns a sequence where five men with machine guns dressed in back decapitate American journalist Daniel Pearl (the actual beheading is not shown, but Pearl's bloodcurdling cries are audible). Finally, Muslim men are also, albeit indirectly, presented as the perpetrators of violence against women (and homosexuals), as highlighted above.

Non-Muslim men are exclusively shown as actual or possible victims of Islam. The film shows five such images: the blood stained face of a young man after the Madrid bombings; the killing of Daniel Pearl; footage of the murdered Dutch film director Theo 
van Gogh, with the voice of his murderer, Mohammed B, played as part of the footage, in which he declares that if he had the chance to repeat the murder, with the help of God, he would. Finally, Wilders himself appears in the film in the form of newspaper items concerning a jihad against him.

The narrative that articulates these roles into a coherent traditional gender discourse of male activity versus female passivity is that of men fighting over the control of women and femininity: Muslim men as individuals or as collective are shown as perpetrators who preach and enact violence, oppress and abuse Muslim women; nonMuslim women and some men, especially homosexuals, are cast as real or future victims of this aggression, specifically within the Dutch national context. White Dutch male heroes, embodied in the figures of Theo van Gogh and Geert Wilders himself, are seen to come to the rescue of non-Muslim women and (homosexual) men, as well as of those Muslims supposedly directly oppressed by Islam. This imagery and narrative are similar to the representation of Islam and Muslim women in more mainstream media, in which their oppression is a key trope, articulated in recurrent coverage of, among other things, forced marriage, honour violence, female genital mutilation and Sharia law (Poole, 2002). The visual dominance of diverse kinds of Islamic headwear for women in Fitna also coincides with mainstream media coverage, in which hijab, niqab, jilbab, burqa and headscarf are treated as a singular sign of female oppression and Islamic 'Otherness'; more specifically: as religious and cultural otherness that is at odds with (European) national values (e.g. Duits and van Zoonen, 2006).

In addition, while Islam is not tied to one particular ethnicity, the representation of Islamic 'Others' as a tied knot of male perpetrators and female victims, is part of a 
particular racist discourse that comes in various forms: it is a reworking of Spivak's well known expression of a protection scenario where the white male hero has to save the 'brown' women from the 'brown' men (as summarised in Stabile and Kumar, 2005)., Leila Ahmed (1992) has demonstrated how a similar scenario was used to justify the occupation of Egypt in the 1880s by Britain: superior Christian invaders had to rescue and liberate Muslim women from Muslim men. More recently Stabile and Kumar (2005:771) have shown that the American invasion of Afghanistan was premised on comparable arguments, namely the noble ideal of protecting women combined with a civilizing mission brought into 'an uneasy alliance to justify the destruction of a country's infrastructure in order to protect women'. These analyses more generally draw on Edward Said's understanding of 'Orientalism' as a stereotypical representation of the peoples of the Middle East that unmistakably helped to legitimate Western imperialist occupation and oppression.

It is worth highlighting that whilst Fitna relies on reproducing and maintaining such an Orientalist agenda is does not simply re-show familiar images, but rather includes images not familiar to most audiences and not deemed acceptable by the mainstream media, as has been recognized by various critics of Fitna (e.g. Kabeer, 2008). Moreover, the mainstream media should not be seen as straightforwardly homogenous in the ways in which it represents Muslims. For example Meer et al. (2010) have recently found examples of 'enlightened' editorials in The Independent in relation to Muslim women's headdress, following the 2006 'veil controversy' in the United Kingdom involving the then Home Secretary and Foreign Secretary Jack Straw. 
Ironically, the protection scenario, in which the wellbeing of Oriental (and nonOriental) women depends on the benevolent intervention of non-Muslim Western men, is not far removed from the patriarchal order it allegedly counters; in both cases, women are denied agency, and appear as victims whose safety lies in the hands of male protectors be it Muslim men protecting women's bodies from the corrupting, penetrating gaze of Western imperialism, or non-Muslim men liberating the same women from the oppressive bonds of Islam. In an Australian context Chalmers and Dreher (2009) have recently also pointed to such safeguarding of masculinity coupled with a discourse concerned with the protection of 'our' borders highlighting the use of a similar 'feminized security rhetoric'.

In its extreme repetition of existing stereotypes and prejudice about Islam, Fitna hardly merits special analysis. Yet, the video had an unexpected poignant side-effect that is more worthwhile: thousands of people from around the globe, a number of whom were women, responded by producing and uploading their own videos to YouTube. These videos contain the views of Muslims and non-Muslims, and some include their experiences and understanding of Islam. They thus offer the opportunity to focus on how women themselves articulate their position in relation to Islam, thus recognizing them as independent actors and hearing their voices. Before we analyse this set of videos, we will discuss our approach and methods. 


\section{Method}

Videos on YouTube seem to produce easy data that allow for non-obtrusive measures. Yet, as a data-archive it is in constant flux, with new videos constantly added, others taken down, and posters sometimes suspended all together. Our initial search for videos resulting from the search terms 'Fitna Wilders', kept throwing up changing numbers of relevant videos (around 3000), with many double counts as well. To counter the variability of the material, the problems with manually coding the metadata associated with each video and the unreliability of the poster information as displayed on their channel, a customized e-research tool was developed for us by Mike Thelwall of the University of Wolverhampton. The tool identifies unique videos and automatically codes all metadata, allowing an accurate snapshot of the site, and providing access to the original registration of the posters (for detailed information about the e-research tool see Vis and Thelwall, 2010) ${ }^{\mathrm{iv} .}$ We are aware that this registration information can only be taken at face value and we can only go on the data the posters have volunteered themselves. At the end of September 2009 ten different keyword searches resulted in a total of 1413 videos that came from unique registrations and of which 200 were uploaded by users registered as female. These latter videos form the basic material for the analysis in this paper.

We conducted a quantitative and qualitative content analysis of these videos that was meant to answer our overall research question, namely whether and how the representation of gender and Islam in these videos differs from the representation of gender and Islam in Fitna. We were especially interested to find out whether and how the female posters presented an alternative discourse about gender and Islam, in which 
women are shown as active agents of their own lives, rather than as victims in need of rescue. We divided this question into four sub-questions that informed our quantitative and qualitative coding of Fitna and the response videos:

1. What are the socio-demographic characteristics of the women uploading the response videos (age, nationality, religion)?

We based this information primarily on the registration data of the female posters. Whilst religion is not entered in the registration information, this could partly be gauged from other personal information (for instance when the Quran was listed as favourite book) and from the videos themselves. We assumed that these characteristics would show that the YouTube debate draws in more diverse participants than mainstream media reporting. Our basis for comparison comes from two studies about Dutch and British newspaper coverage of Fitna (Ruigrok et al. 2008; Knott et al., 2010).

2. What are the generic and ideological characteristics of Fitna and the videos uploaded by women?

We registered the length and the genre of the video drawing distinctions between content simply uploaded from mainstream sources such as news and current affairs programmes ('cut and paste') and genres where content could be said to be more user generated, as in mixing text, music, still and moving images from a range of sources ('cut and mix'), the simple, personal style of the piece to camera ('testimonial') among others (cf. Van Zoonen, Müller and Hirzalla, 2009). We also assessed the religious and political voice of the female posters, analysing whether and how they 
criticized or supported Fitna and whether they expressed a position on the Islam debate more generally.

3. How are women and men from Muslim and non-Muslim backgrounds represented in Fitna and in the response videos? Within each separate video, we took individuals, groups and crowds as units of measurement and coded, in addition to gender, for the following variables:

a. visible identification as Muslim or not (through styles of dress, most notably through religious apparel such as the hijab). Our assumption was that the women's videos would show a larger diversity of visual images of Muslims than those shown in Fitna, and, for instance, include Muslim women not wearing head- or body coverage;

b. the social presence of women and men, in terms of presence (alone, in group, in crowd), context (e.g. public, work, domestic) and interaction (conversation, demonstration, conflict, etcetera). Our expectation was that the women's videos would contain more diversity than Fitna;

c. visual and audio presence of women and men, as a moving or still image, as voiceover or in the form of written text (for instance a written quote). Our expectation was that the women's videos would involve a more active audio-visual presence of Muslim women than the Fitna video did;

4. What kind of alternative stories do female posters tell about Islam? On the basis of the quantitative coding we selected one particular set of videos uploaded by a group of young Egyptian women for a more detailed narrative analysis in order to show how 
they constructed alternatives to Orientalism and how they discussed their video with others on YouTubev.

\section{Female posters on YouTube}

When we collected our data at the end of September 2009, female posters had uploaded 200 video responses to Fitna. While a few of them had responded as early as February, linked to the widely circulating rumours about the film, most of them uploaded their video around the time of its release in March 2008 and in the months immediately after. The majority of women (sixty-two) uploaded one single video, thirteen uploaded two, three or four videos, and one poster uploaded ninety four videos in the summer of 2009 (see figure 1). This latter poster calling herself quranmiracles and was registered as a 55year old woman from the West African country of Togo. Apart from using the tags 'Wilders' and 'Fitna', the quranmiracles videos did not address Fitna directly, but contained conversion videos of ordinary people as well as celebrities celebrating Islam. By the end of 2009 YouTube had suspended this user for reasons that could not be identified on YouTube, or from other sources. ${ }^{\mathrm{vi}}$

\section{[Figure 1 approximately here]}

For our analysis, we concentrate on the months of February, March, April and May when most films (seventy) responding directly to Fitna were uploaded. Seven of them had to be excluded (for example because they referred to the Bollywood movie Fitna Dill), leaving sixty three videos uploaded by forty six individual posters for analysis. Amongst these 
videos, we found Fitna itself (or parts thereof) seven times in a range of translations, including Farsi and Polish. The forty six posters came from eleven different countries, with the Netherlands (Geert Wilders' home country) predictably leading, but with Egypt as second with twelve posters. On closer inspection these turned out to consist of a group of Egyptian young women who, it seems, had come together specifically to make a two part response to Fitna, and whose videos came up sixteen times in the material. We will come back to their videos in the last section.

\section{[Table 1 approximately here]}

Most of the posters were younger than thirty, with an average age of 28.9, according to their registration. While the quranmiracles poster was listed as 55 years old, this was an evident exception. Whilst listing your religion is not part of the YouTube registration, a few posters provided other kinds of indicative information (for instance listing the Quran as their favorite book), but of those few that did refer to their religion more mentioned Islam than Christianity.

In comparison to the coverage of Fitna in the Dutch and the British press, these data suggest that YouTube offers a space for the kinds of citizens that are regularly ignored in mainstream debate: an analysis of Dutch press coverage found that the sources and voices talking about Fitna consisted by and large of national experts, political actors and Wilders himself. Ordinary citizens were relatively absent from the debates (Ruigrok et al., 2008). Research about British news coverage of Wilders and his film produced 
similar outcomes: English cabinet members, politicians and experts dominated the press coverage, while the voices of Muslims were mostly absent (Knott et al., 2010). In contrast, the YouTube videos offer a more international perspective, allow younger women to speak and offer a voice to Muslims.

\section{The videos}

The sixty-three videos were widely different in content and form, as can be expected in an open platform like YouTube. Among them were seven videos of Fitna itself (or parts thereof), including Polish and Farsi translations. Other videos (fourteen) were simply 'cut-and-paste' productions in which the poster did not add her own material, but simply uploaded copies of news items, current affairs programs, documentaries, cartoons or other existing audiovisual work. Most of the videos, however, were amateur videos in the form of cut-and-mix productions (eighteen) that used existing still and moving images in combination with text and music to make an original statement. A recurring theme in these cut-and-mix videos is imitation of Fitna, but with Christianity replacing Islam, for instance using violent texts from the Bible, illustrated by sounds and images. ${ }^{\text {vii }}$ Other examples include, for instance, a fairly simple one minute and nineteen seconds video without sound, which is titled 'Anti-Wildersfilm', and described in the channel section as 'a film about the super awful stupid nasty Geert Wilders'. It is a sequence of images of hand-written texts on a white background (e.g. 'Geert Wilders sucks'), original and morphed pictures and cartoons of Wilders, which ends with 'made by anonymous'. viii Other such videos also contain pictures of Wilders morphed into singing strange songs, or fragments of texts (for instance from the Quran) on a simple unicolor or picture 
background. The organized response from a group of Egyptian Muslim women was constructed in this way. Following the opening shots and sounds of the original Fitna, yellow letters appear on a black background:

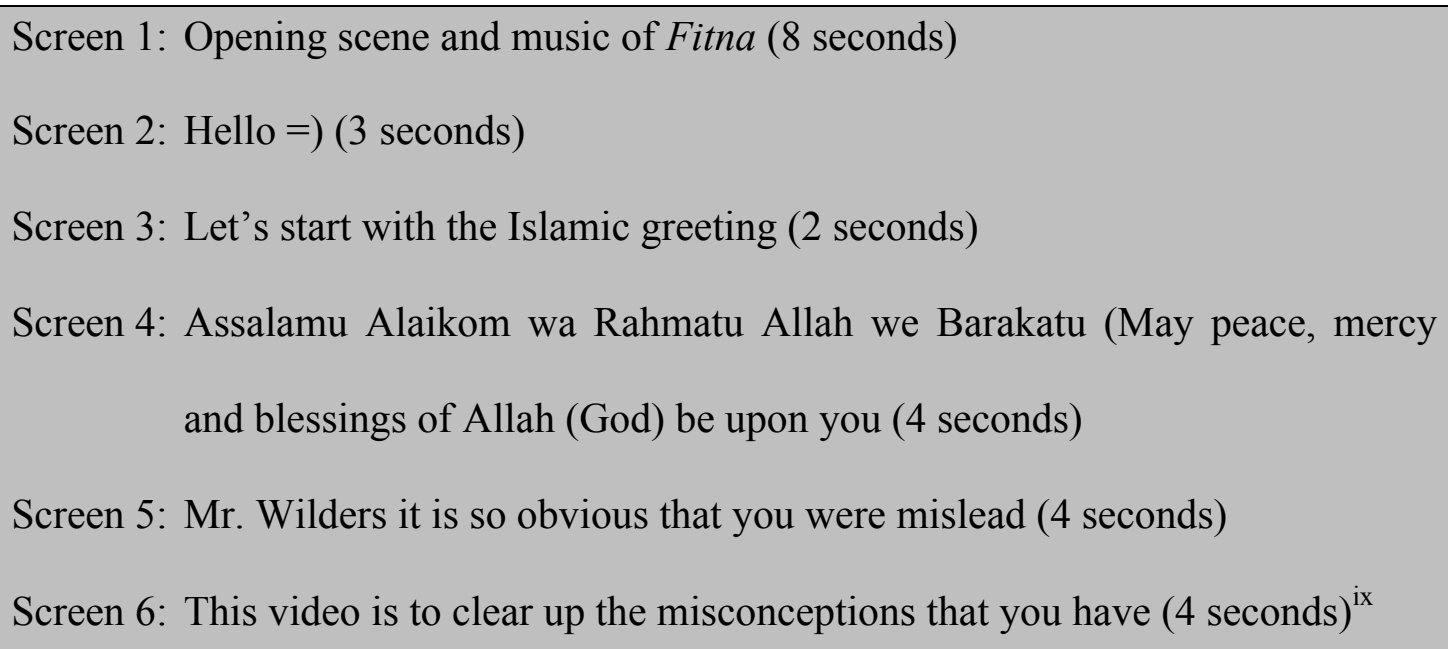

Other home-made videos could be typified as testimonials of women talking to camera and commenting on Fitna and/or Islam. One of them was the response of a British girl to the famous YouTube call from Queen Rania of Jordan to 'send me your stereotypes' of Muslims which she would then try to counter (Jones, 2008).

Four parts of an original film commissioned by the independent Dutch TVproducer MTNL, specialized in multicultural programming and hosting its own channel on YouTube, were somewhere between amateur and professional production. The film called 'De Tegenfilm' (The Countermovie), is a 30 minute production about the search of a Dutch-Turkish Muslim TV producer for a suitable answer to Geert Wilders. It offers an ironic view of the alleged Islamization of the Netherlands and explains Wilders' 
islamophobia by exploring his youth traumas, psychological insecurity and lack of attention. Table 2 shows the distribution of the genres of the videos in numerical terms:

\section{[Table 2 approximately here]}

The majority of these videos (forty) demonstrate a clear critical position towards Fitna: they criticize and make fun of Wilders, analyse the visual rhetoric of the film, or offer alternative readings of Islam. The cut-and-paste videos of existing news and current affairs footage are generally neutral. Only two videos (apart from the seven reloads of Fitna itself) express univocal support for Wilders: a poster called inbenproWilders (including a typo, this probably means 'I am pro Wilders'), uploaded one 2.51 minute silent video, showing white English and Dutch texts on a blue background, opening with the sentence: 'Geert Wilders, is he right or wrong?', and then presenting a range of presumably relevant 'facts', provided without offering any evidence. These for example highlight that the majority of prisoners and those receiving welfare benefits in the Netherlands are not Dutch, and that the mayor of Amsterdam, Job Cohen, is well known for drinking tea with criminals. The second video uploaded in support of Wilders is a thirty second announcement of 'the ultimate movie to expose the death cult 'islam' and refers audiences to a 'banislam.blogspot'. ${ }^{\mathrm{x}}$ 
This part of our analysis thus demonstrates that YouTube offers an alternative space to express one's opinions in different formats than those of mainstream media coverage; cut-and-paste and testimonials are the typical YouTube genres that young women from Muslim and non-Muslim backgrounds (otherwise marginalised actors) used to criticize Geert Wilders and his film. Looking at the total number of views for these videos, it is also clear that this is not a marginal space: 677,125 views were registered for all videos and the average number of views per video was $12,311{ }^{\mathrm{xi}}$ The first ten minutes of De Tegenfilm (The Counterfilm), for instance, drew 140,000 views; the videos of the Egyptian girls were accessed over 9,000 times in total. On the other hand, a video by rosefire 18, text on background about the wonders of Islam, was accessed 28 times only. This was exceptionally low, however, and the only video that attracted less than 100 views.

The next question is whether the alternative space constructed by the videos also signifies a departure from the Orientalist discourse that underlies Fitna, through different imagery and narratives of women. We explored this question by analysing the portrayal of individual men and women appearing in the videos.

\section{Different representations of women?}

A number of the YouTube cut-and-mix videos did not portray individual people at all, but simply presented written text on static background. Most of the people that do appear in these videos are male; $71.3 \%$. In addition, while the majority of people in the videos appear in their role as citizens, twice as many men as women appear as public officials. ${ }^{\text {xii }}$

Yet, within this overall, seemingly stereotypical context, there are remarkable differences 
between the representation of women and men that also demonstrate a clear alternative to the Orientalist extremism of Fitna.

\section{A. Visual Identification}

An important difference between Fitna and the YouTube videos of women, concerns the presence of the headscarf and other Islamic headwear. Table One shows that Fitna contains more of these and other sartorial indicators of Islam - for women and for men than the YouTube videos do:

\section{[Table 3 approximately here]}

We saw in the description of Fitna above, that the sartorial indicators of Islam function as a key visual marker of 'Otherness', for Muslim women and men alike. The headscarf specifically operates in Fitna as a sign of the alleged oppression of women in Islam. The relative absence of such visual markers in the videos of women themselves, suggest that such an easy construction of difference between women and men, and between Muslims and non-Muslims is less feasible. The videos that they uploaded contain more diverse sartorial images of men and women.

\section{B. Social Presence}

The extremist image of Islam in Fitna is constructed by portraying Muslims in the particular social contexts of religious hate speech and terrorism, and presenting nonMuslim men and women as victims, as we described above. This observation also emerges from the quantitative comparisons of social contexts in which women and men 
appear in Fitna. Table 4 it shows that almost half of the individual men appearing in Fitna occur in a religious context, whereas another 20 per cent are cast in conflict situations. A third of the women shown in Fitna occur in conflict situations (as victims as we described above), and a third in public spaces (with their bodies and faces more or less covered and functioning as icons of Otherness). In contrast, the women and men shown in the YouTube videos of women appear in the more everyday settings of work, and in religious contexts. The excessive association in Fitna of Islam with terrorism and conflict is largely absent from the YouTube videos.

\section{[Table 4 approximately here]}

\section{Audio and Visual Presence}

The audio and visual presence of women and men in Fitna and the YouTube videos of female posters clearly differed. From Table 5, it is evident that in Fitna, almost half of the women appeared as still image, further underlining their passive and voiceless status in the film. The majority of men in Fitna appeared as moving and speaking image, with the fragments from extremist Islamist preachers dominant, contributing to the impression of male Muslims as aggressors. The overall presence of women and men in the YouTube videos is almost the complete opposite: although there were fewer women than men appearing in the videos, their presence was much stronger in terms of the length and audiovisual importance of their appearance. The majority of women in the films appear as moving and speaking image, or are portrayed through a combination of text, still image, voice over and moving image. Half of the images of men in the videos, on the 
other hand, are brief 'image bites' of less than ten seconds (50.2), whereas the images of women generally lasted some ten seconds longer. Moreover, more women than men were given a sustained and long presence in the videos: 15 per cent of the women versus 12,5 per cent of the men were shown longer than three and a half minutes. ${ }^{\text {xii }}$

\section{[Table 5 approximately here]}

\section{The voice of Muslim women}

In the YouTube videos, we found a number of instances in which Muslim women took or were given a voice to speak about Fitna or Islam. A first and very brief one, from mainstream media coverage, comes from a cut-and-paste video of a Dutch discussion program in which Yassmina El Ksaihi, speaking on behalf of an organisation working with Dutch citizens of Moroccan heritage, and wearing a bright pink hijab, summarizes in nine seconds that if Wilder's goal was for Dutch Non Muslims to turn against their fellow Muslim citizens she thought he had failed. ${ }^{\text {xiv }}$ In The Countermovie, set in the Netherlands, a fictitious female Muslim newsreader wearing a light blue hijab reads the 'News of Yesterday' announcing among other things that it has been five years ago since the Sharia was introduced in the Netherlands, and that Geert Wilders failed his civics exam 'I am Halal', for the fifth time. As part of the testimonial genre, we found a voice only video (without images) from a young Muslim woman speaking out against Fitna arguing that Wilders took Quranic verses out of context, herself highlighting their meaning in the clip, and furthermore questioning his authority to interpret them at all. ${ }^{\mathrm{xv}}$ 
Of all the uploaded videos the concerted effort of a group of young Egyptian women is the most elaborate and consequential example of Muslim women speaking for themselves. They produced two videos (one of 9.37 minutes and one of 9.59 minutes) to respond to Fitna and uploaded them around the end of April 2008, using different YouTube accounts, some of which were clearly set up for this purpose alone. Users with names such as TruthAboutFitna08, ZTruthAboutFitna and Fitnamovie2008 only uploaded these response videos and their channels have since ceased to be active. After its opening sequence addressing Wilders and stating the purpose of the film ("to clear up the misconceptions that you have", see above), the film then proceeds to go through the Quranic verses used in Fitna. A female voice-over reads the verse, which is followed by written texts of different colours on black background explaining their meaning and putting them in the context of the complete verse they were taken from. ${ }^{\text {xvi }}$ With this approach, the makers of the video identify the $9 / 11$ perpetrators as sinners in the eyes of Islam. Apart from being an exceptional reaction to Fitna, the video is also a rather unique intervention of women with respect to religious authority that may be typical of the Egyptian women's mosque movement (cf. Mahmood, 2005). First, the pure act of women reading out verses from the Quran in the semi-public and mixed gender space that YouTube constructs, is a performance of religious identity that is hardly feasible in the offline context, where it is highly contested whether women are allowed such acts outside of women only groups. Second, the additional act of women interpreting the true meaning of the Quranic verses is also rather uncommon and puts these videos right at the heart of liberal modern Islam. Whether these Egyptian posters consider themselves part of a wider movement is, however, a question for further research. ${ }^{\text {xii }}$ 
In the second film (starting with 'Hello again'), the women pick up on their assessment of terrorists as sinners, and try to clarify 'why some Muslims Interpret Qu'ran verses in a wrong way and act upon it ${ }^{\text {xviii }}$ They do this by showing a series of pictures and clips about the violent treatment of Muslims around the world. The invasion of Iraq, Abu Ghraib and the occupation of Palestine provide strong images, especially of Muslim women as victims of violence - this time not of Islam as in the Wilders film - but of Western and Israeli war crimes. They end this sequence of harrowing images with the promise of a third film and the text:

Those were some scenes from life in Palestine, Iraq and Lebanon. Where there's a 9/11 everyday... Now, put yourself in their shoes. Invaders killing your kids in front of your eyes, torturing your brothers and destroying your home. EVERYDAY!

Would you be psychologically and emotionally stable? How would you deal with this life? If you have strong faith... Resort to God's help praying him to get rid of those invaders for you! [Or] else... lose control. Muslims who lose control ... are those who try to give themselves the right to take "revenge". So they start interpreting Quran verses in a way, which gives them this right. Now you're starting to see the whole picture. Never hear a story from one side. Think about it.

All versions of these two videos were watched over 9,000 times in total and evoked 169 text comments on YouTube. Strikingly, the different uploads of the same film evoked widely different kinds of discussion. The makers of the videos regularly reacted to the 
comments of the viewers, thanking for positive comments, explaining their motives and discussing different interpretations of the Quranic verses they used. ${ }^{\text {xix }}$

\section{Conclusion and theoretical reflections}

Before we reflect on the wider theoretical ramifications of our findings, we briefly sum up our main conclusions: we began with a description of the portrayal of men and women from Muslim and non-Muslim background in Fitna and concluded that they were framed in a traditional Orientalist narrative in which women are presented as the present and future victims of the oppression of Muslim men and Islam. In such a discourse, which dates back at least to the colonialist enterprise of the eighteenth and nineteenth century, white European, non-Muslim men are constructed as rescuers and protectors. We also observed, on the basis of secondary sources, that mainstream media coverage in Britain and the Netherlands opened up space for experts, civic leaders, politicians and journalists to express their views on Fitna and Islam, but that ordinary citizens including Muslims were rarely given a voice. Our analysis of the YouTube videos uploaded by women showed that YouTube clearly offers an alternative and an important space to discuss

Fitna and Islam. Firstly, the women uploading their videos are a different kind of actor in public debate than the ones participating in mainstream media discussions: they come from across the globe, they are relatively young and many of them are active Muslims. Secondly, while many of them express their ideas by copying and pasting footage from existing media, the majority of the women uploading their videos produced their own material by cutting and mixing images, sound and texts or by speaking directly to the camera in a testimonial. In these alternative expressions, there was only rare support for 
Geert Wilders or a staunch anti-Islam standpoint. On the contrary, direct criticism and ridicule of Wilders were common, as were serious and committed explanations of Islam and how Muslim women themselves interpret their religion. Overall, the portrayals of women and men in the videos were radically different from those in Fitna; although relatively few women appeared in the videos, they were not typified in terms of 'us' versus 'them' through headwear or other sartorial markers; they also received lengthy attention, spoke for themselves and were shown in an everyday ordinary work contexts or in the setting of religion, instead of as victims of conflict, as in Fitna. Women also actively explained and discussed their understanding of Islam, thus not only taking on Wilders, but also claiming their right to speak within Islam.

It thus seems justified to conclude that women, Muslim and non-Muslim, have used YouTube to give themselves both a political and a religious voice in the global Islam debate, in which Fitna presents an extremist position. It also seems legitimate to say that these voices are heard, given the significant amount of views that the total and most individual videos received. Without knowing too much about the background of the posters, our data nevertheless demonstrate how these women constituted themselves as global citizens through their act of copying or making videos and uploading them to YouTube. Notwithstanding the absence of a global polity in which to claim citizen rights and perform citizen duties, their videos are typical 'acts of citizenship', as Isin and Nielsen (2008) have called it, by women claiming their right to speak to wider audiences, and to political and religious actors that have often prevented them from speaking or have not bothered to listen to them. 
Yet, as Isin and Nielsen (2008:38) have argued, acts of citizenship need to be further interrogated for they are not "already inherently exclusive or inclusive, homogenizing or diversifying, or positive or negative. These qualities arise after or, more appropriately, through the act." In other words, the content and the form of the YouTube voices of women also need to be further examined to assess what kind of citizenship is actualized. Following Allison Jaggar's (2000:40) approach to cultural recognition in multicultural democratic discourse, we could analyse acts of citizenship, and by the same token the YouTube videos, on the basis of three virtues, namely 'multicultural literacy, moral deference and openness to reconfigure our emotional constitutions'. Obviously, Fitna itself would not meet these requirements, but neither do many of the YouTube videos. The cut-and-mix visuals that criticize and ridicule Wilders, and some of the testimonials are intentionally closed to a reconfiguration of emotions and are vehicles of anger, rather than expressions of moral deference. In terms of off-line politics, they are thus better understood as demonstrations of one's political and/or religious position than as deliberation in the sense of reasonable discussions between equals about matters of public interest (e.g Elster, 1998). In fact, the only videos in our material that would qualify for the requirements of deliberation and multicultural democracy are the films uploaded by the group of Egyptian women: not only do they open their videos with a respectful greeting to Geert Wilders, they also adapt a more explanatory than argumentative mode of written speech and they engage in polite dialogue with their viewers afterwards.

Nevertheless, it seems unproductive to exclude the demonstrative voice of the other videos and disqualify them for their lack of deliberative qualities. Apparently, we 
need other theoretical instruments to assess their worth. Hirschman's (1970) classic sociological treatment of exit, loyalty and voice as options in whatever kind of social or political community, is more helpful here, and enables an appreciation of the videos as 'voice', defined as 'any attempt at all to change, rather than to escape from, an objectionable state of affairs, whether through individual or collective petition (...), through appeal to a higher authority (...), or through various types of action and protest including those that are meant to mobilize public opinion" (30). Such a concept of 'voice' does more justice to the other videos in our sample also, and involves an attempt at solving things together rather than going one's separate way.

It is of course important to note that in its original development, Hirschman's treatment of voice concerned voicing protest to management or the state. In the global Islam debate, of which Fitna and the YouTube videos are a part, there is no authority to speak to, and the question thus remains as to whom voice is directed and who is listening (e.g. Bickford, 1996). Our data did show that women's voices are certainly 'heard' and seen, but we got little information about how exactly they are listened to and made sense of, with the exception - again - of the videos of the Egyptian women. Following Crawford's (2009) analysis of listening in social media, a form of reciprocal listening occurred there, involving a two-way process between speaking and listening, clearly visible in the comment threads sparked by the videos uploaded by Egyptian posters. Still, we could argue that other videos in our sample also constituted voices that were acknowledged. According to Mitra and Watts' (2002) theorizing of the notion of 'voice' in cyberspace, 'the moment in which voice is actualized as an event, when it becomes an answerable phenomenon, is when it is acknowledged' (484). Following that logic, the 
pure act of uploading your video to YouTube produces by definition an acknowledged voice, because the technological capabilities of the platform (the options to respond with text and new videos) make it immediately into an answerable phenomenon, whether actually listened to or not. And so, we come back full circle to the act of citizenship: whether typified as deliberation or as voice, in both cases the simple act of uploading a video to intervene in the global Islam debate, has constituted those women as citizens albeit temporarily - thus countering the debilitating discourse of Orientalism, and rendering them simultaneously answerable and accountable to others who hold different or similar opinions.

To sceptics, such on-line acts of citizenship and alternative voices may seem inconsequential. Indeed, these voices and acts so far failed to provoke repercussions in mainstream debates, and instead remained enclosed in the 'public sphericules' created by alternative communicative platforms, thus contributing to 'two-tier' society and a segmented public sphere (Gitlin, 1998). Yet whose responsibility is it to establish the feedback loops that would allow such alternative voices and acts of citizenship to partake in an active encounter with voices in the mainstream, and thus establish a truly public and democratic debate capable of reaching across identity barriers and social and ideological differences? In line with recent work on the politics of voice and listening (Couldry and Dreher, 2007), surely we cannot blame the fragmentation and polarization of public debates about Islam in the West on the alternative communicative platforms and their participants themselves, or expect all solutions to come from them. In the case of Fitna, ordinary citizens posting their videos on You Tube did their bit. The onus is now on the mainstream gatekeepers of the mainstream public spheres in the West to allow these 
voices to be heard on a wider scale, and counter the fragmentation and polarization of debate they have themselves helped create.

\section{Word count (including notes and references): 6969.}

\section{Notes}

i Wilders said this in an interview with a Dutch newspaper, Volkskrant, October 7, 2006. Retrieved on July 6, 2010, http://www.volkskrant.nl/binnenland/article577161.ece/

ii This work is part of a larger research project, which includes further work on the complete corpus of 1413 videos. This project, led by Liesbet van Zoonen, is funded under the Religion and Society programme by the AHRC and ESRC (AH/GO16631/1). See: http://www.lboro.ac.uk/departments/ss/research/FITNA/index.html 
iii Abu Hamza al Masri was detained by the British authorities in 2004 on allegations of terrorism; Al Samarai was a supporter of Saddam Hussein who has not been seen since 2003.

iv The tool can be downloaded for free from http://lexiurl.wlv.ac.uk/searcher/youtube.html

$v$ The full coding sheet is available from the project website.

${ }^{\text {vi }}$ While we had archived the quranmiracles videos, her suspension (along with her whole channel and all videos) made it impossible to get in touch with this poster for more information and to gain clarification.

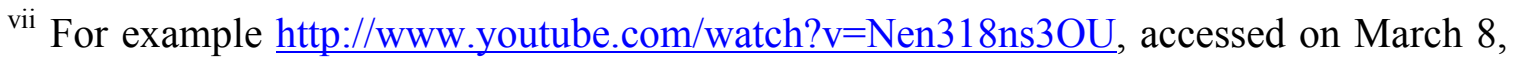
2010, see also Van Zoonen, Hirzalla and Müller (2009).

viii All translations from Dutch by the authors, URL: http://www.youtube.com/watch?v=0AkRAG6Yyfs, accessed on March 8, 2010.

${ }^{\text {ix }}$ http://www.youtube.com/watch?v=mfcA41PCcoo, accessed on March 8, 2010.

x http://www.youtube.com/watch?v=f0ET9qez-Ks, accessed March 8, 2010.

xi Calculated on the basis of viewing numbers on March 9, 2010. Excluding the reloads of Fitna, the call of Queen Rania which attracted over a million views by itself, and three videos that were removed by that day because of copy right issues.

xii The significance of the coded differences was tested with the $\mathrm{X}^{2}$ test for association of nominal variables $\left(\mathrm{X}^{2}=32, \mathrm{p}=.01\right)$. 
${ }^{\text {xiii }}$ Ibid, $\left(X^{2}=55.5, p=.05\right)$.

${ }^{\text {xiv }}$ http://www.youtube.com/watch?v=frZmIZTHC04, accessed February 12, 2010.

${ }^{\mathrm{xv}}$ Title: Re Fitna the movie. URL: http://www.youtube.com/watch?v=pF0AANuODOU

${ }^{\text {xvi }}$ http://www.youtube.com/watch?v=Kw4TjTtlWCU, accessed March 8, 2010.

${ }^{\text {xvii }}$ We analysed the motives and aims of the posters in another part of the research. See http://www.lboro.ac.uk/departments/ss/research/FITNAindex.html

xviii http://www.youtube.com/watch?v=qK2VErvUHww, accessed February 12, 2010

${ }^{\text {xix }}$ We cover the discussions that followed these and other videos that were uploaded in response to Fitna in: Van Zoonen, L. Van, Mihelj, S. and F. Vis (under review). YouTube interactions between agonism, antagonism and dialogue: video responses to $\begin{array}{llll}\text { the } & \text { anti-Islam } & \text { Fitna. }\end{array}$ http://www.lboro.ac.uk/departments/ss/research/FITNA/index.html

\section{References}

Ahmed, L (1992) Women and Gender in Islam: Historical Roots of a Modern Debate, New Haven: Yale University Press.

Aly, A (2009) 'Media Hegemony, Activism and Identity: Muslim Women Representing Muslim Women' in Dreher and Ho (2009).

Bickford, S (1996) The Dissonance of Democracy: Listening, Conflict and Citizenship, 
Ithaca, NY: Cornell University Press.

Chalmers, S and Dreher, T (2009) 'Safeguarding Masculinity, Protecting “our” Borders:

The Banality of Sexual Violence in the Public Sphere in Australia' in Dreher and Ho (2009).

Choua, N and Kranenberg, A (2008). 'Fitna ontleed: de film beeld voor beeld' Volkskrant, April 15.

http://www.volkskrant.nl/binnenland/article527366.ece/Fitna_ontleed (accessed 6 July 2010)

Crawford, K (2009) 'Following You: Disciplines for listening in social media' Continuum: Journal of Media and Cultural Studies, Vol. 23, No. 4:525-535. Couldry, N and Dreher, T (2007) 'Globalization and the Public Sphere: Exploring the Space of Community Media in Sydney', Global Media and Communications, Vol. 3, No. 1: 79-100.

Duits, L and van Zoonen, L (2006) 'Headscarves and porno-chic: disciplining girls' dress in the European multicultural society' The European Journal of Women's Studies, Vol. 13, No.2:103 - 117 .

Elster, J (1998) Editor, Deliberative Democracy, Cambridge, Cambridge University Press.

Gitlin, T (1998) ‘Public Sphere or Public Sphericules?’ in Liebes and Curran (1998). Hirschman, A (1970). Exit, Voice and Loyalty: responses to decline of firms, organizations and states. Cambridge, MA: Harvard University Press. Isin, E F, and Nielsen, G M (2008) Editors, Acts of Citizenship, London: Zed Books. Jaggar, A (2000) 'Multicultural Democracy’ in Chambers and Costain (2000). 
Jones, B (2008) ‘Queen Rania takes on stereotypes’ BBC NEWS, Friday 25 July 2008, http://news.bbc.co.uk/2/hi/middle_east/7524933.stm, accessed 8 March 2010.

Kabeer, S (2008). 'Geert Wilders, "Fitna," and the last refuge of the bigoted' Global Comment, where the world thinks out loud, 14 April 2008, http://globalcomment.com/2008/geert-wilders-Fitna-and-the-last-refuge-of-the-bigoted/, accessed 5 March, 2010.

Knott, K, Poole, E and Taira, T (2010). 'Media portrayals and the secular sacred' Presentation to Loughborough University, Department of Social Sciences, 5 March 2010. Mahmood, S (2005). Politics of Piety: The Islamic revival and the feminist subject, Princeton, NJ: Princeton University Press. Meer, D, Dwyer, C and Modood, T (2010) 'Embodying Nationhood? Conceptions of British national identity, citizenship, and Gender in the 'Veil Affair' The Sociological Review, Vol. 58, No.1:84-111.

Mitra, A and Watts, E (2002) 'Theorizing cyberspace: the idea of voice applied to the internet discourse' New Media and Society, Vol. 4, No.4:479-98.

Moore, K, Mason, P and Lewis, J (2008) Images of Islam in the UK: The Representation of British Muslims in the National Print Media 2000-2008. Cardiff, Cardiff School of Journalism, media and cultural studies.

Poole, E (2002). Reporting Islam. Media representations of British Muslims, London: I.B. Tauris.

Poole, E and Richardson, J E (2006) Editors, Muslims in the News Media, London: I.B.Tauris.

Richardson, J E (2006) 'Who Gets to Speak? A Study of Sources in the Broadsheet Press' 
in Poole and Richardson (2006).

Ruigrok, N, Scholten, O, Krijt, M, Schaper, J and Paanakker, H (2008) Fitna en de media: Een onderzoek naar aandacht en rolpatronen. [Fitna and the media: A research into attention and source roles], Amsterdam: Dutch New Monitor.

http://www.nieuwsmonitor.net/list (English summary available, accessed 6 July 2010).

Stabile, C A and Kumar, D (2005) 'Unveiling imperialism: media, gender and the war in Afghanistan' Media, Culture and Society Vol. 27, No.5:765-82.

Vis, F and Thelwall, M (2010) 'Challenging dominant representations of Islam online: innovative methods for studying YouTube' Innovative Methods in the Study of Religion Conference, London, 29-30 March 2010.

Zoonen, L van, Müller, F and Hirzalla, F (2009). 'De slag om Fitna [Fitna, the video battle]' in Aarts and van der Haak (2009). 